Más allá de la dicotomía sobre la protección

y manejo de los mamíferos marinos en Japón

\title{
Beyond dichotomy in the protection and management of marine mammals in Japan
}

\author{
Hiroyuki Matsuda ${ }^{*}$, Orio Yamamura ${ }^{2}$, Toshihide Kitakado ${ }^{3}$, Yumi Kobayashi $^{4}$, Mari Kobayashi ${ }^{5}$, Kaoru Hattori ${ }^{6}$, and \\ Hidehiro Kato ${ }^{7}$
}

\begin{abstract}
'Faculty of Environment and Information Sciences, Yokohama National University, 79-7 Tokiwadai, Hodogaya, Yokohama 240-8501, Japan. E-mail: matsuda@ynu.ac.jp (HM).

${ }^{2}$ Hokkaido National Fisheries Research Institute, 116 Kasurakoi, Kushiro, Hokkaido 085-0802, Japan. Email: orioy@affrc.go.jp (OY) ${ }^{3}$ Department of Marine Biosciences, Tokyo University of Marine Science and Technology, 4-5-7 Konan, Minato, Tokyo108-0075, Japan. E-mail: kitakado@kaiyodai.ac.jp (TK).

${ }^{4}$ Graduate School of Fisheries Sciences, Hokkaido University, Hakodate, Hokkaido 041-8611, Japan. E-mail: kobayumi@fish. hokudai.ac.jp (YK).

${ }^{5}$ Department of Aqua-Bioscience and Industry, Faculty of Bioindustry, Tokyo University of Agriculture, Abashiri, Hokkaido 0992493, Japan. Email: m3kobaya@bioindustry.nodai.ac.jp (MK).

${ }^{6}$ Hokkaido National Fisheries Research Institute, 116 Kasurakoi, Kushiro, Hokkaido 085-0802, Japan. E-mail: orioy@affrc.go.jp, khattori@affrc.go.jp,kkaji@cc.tuat.ac.jp (KH).

${ }^{7}$ Department of Ocean Sciences, Tokyo University of Marine Science and Technology, 4-5-7 Konan, Minato, Tokyo108-0075, Japan. E-mail: katohide@kaiyodai.ac.jp (HK).

${ }^{*}$ Corresponding author
\end{abstract}

Introduction: Marine mammals are natural resources for humans. They are also considered as pests in some fisheries. Damage to fisheries by Steller sea lions in northern Japan has increased since the 1990s. The major factor that drives the relationship between humans and marine mammals has changed from the middle of the $20^{\text {th }}$ century to the early $21^{\text {st }}$ century; this is the result of changes in the extent to which their populations are threatened, the demand for these natural resources, and policies for marine mammal conservation.

Methods: In this paper, we have chosen four major taxa of marine mammals to investigate changes in policies for marine mammals in Japan: Steller sea lions, harbor seals, dugong and cetaceans. Some cetacean species have been overexploited in the past and remain threatened. Their full recovery is still awaited. Other large cetacean species have never been threatened; nevertheless all commercial whaling was placed under a moratorium by the International Whaling Commission in 1982.

Results: Japan still catches small cetaceans in coastal whaling operations and large cetaceans for scientific research. Except for cetaceans, the policy for marine mammals has changed from resource use in the middle of the $20^{\text {th }}$ century, to protection in the late $20^{\text {th }}$ century, and to nuisance control since 2014 . Environmental groups played an important role in building consensus for these policy changes.

Discussion and conclutions: We seek a comprehensive policy that achieves a balanced approach to accommodate three different roles of marine mammals: a natural resource, participants in marine ecosystems and agents of damage to fisheries. We also discuss the importance of stakeholder involvement in changing policies for wildlife management, ranging from complete protection to population control.

Key words: Adaptive wildlife management; japanese commercial whaling; dugong, Harbor seals; population control; stakeholder involvement; steller sea lion. 


\section{Introduction}

Marine mammals are natural resources for humans. Their uses include food, furs and oil (Pompa et al. 2011). Marine mammals are an important part of ecosystems. In terrestrial ecosystems, mammals are either herbivores, insectivores, carnivores, omnivores or scavengers. Some mammals also play an important role in seed dispersal and even pollination. In marine ecosystems, marine mammals are either herbivores, planktivores, piscivores or carnivores. Baleen whales often feed on both plankton and small fish. Overall, they consume more fish than are taken by fisheries (Tamura et al. 1998). In addition, marine mammals often conflict with fisheries. Japanese traditionally feed on a variety of fish, invertebrates, seaweeds and marine mammals. In Ishigaki Island, Okinawa, Japan, the dugong (Dugong dugon) was used for a tax to Ryukyu Dynasty (Ouhama 1971, Hosono et al. 2009). Recently, only three individuals were found surrounding Okinawa Main Island and no individuals were reported from other parts of Japanese waters (Okinawa Defense Bureau 2012). The dugong was listed as Critically Endangered in the Japanese Redlist for 2012.

In addition, some marine mammals are considered as pest animals for fisheries (pest referring to a species that may include some animals that are a nuisance). Steller sea lions (Eumetopias jubatus jubatus) and harbor seals (P. vitulina stejnegeri) have damaged gillnet and set net fisheries in Hokkaido and Aomori Prefectures, northern Japan. The Hokkaido prefectural government has compiled lists of direct and indirect damage caused by Steller sea lions to fisheries since the 1989 fiscal year. Direct damage refers to the damage caused to fishing nets by attacking the fish already caught in the net, whereas indirect damage is the sum of losses of fishing opportunities and of yield due to depredation. Both direct and indirect damage on fisheries by Steller sea lions has increased since the 1990s. The direct damage to fisheries by Steller sea lions in Japan was calculated at ca. 270 and 490 million JPY in 1990 and 2012, respectively (as shown in Figure 1). The indirect damage was ca. 190 and 1000 million JPY in 1990 those same two years. The indirect damage caused by earlier closing of the fishing season is uncertain as additional catches of fisheries resources may reduce stock abundances in future. Although direct damage to fisheries by cetaceans is not known, an increase in cetacean populations may lead to a decrease in fisheries resources (Tamura et al. 1998). This is amongst the reasons why the Japanese Fisheries Agency has argued that it is necessary to restart commercial whaling, based on the premise of fisheriescetaceans conflict. There is still scientific controversy concerning the interactions of cetaceans and fisheries resources (Yodzis 2001).

The major factor that drives the relationship between humans and marine mammals changed from the middle of the $20^{\text {th }}$ century to the early $21^{\text {st }}$ century as a result of changes in the extent to which their populations are threatened, demand for these natural resources and policies for marine mammal conservation. In this paper, we choose four major taxa of marine mammals to investigate the change in policies for different marine mammals in Japan: Steller sea lions, harbor seals, dugong and cetaceans. Except for cetaceans, the policy for marine mammals has changed from resource use in the middle of the $20^{\text {th }}$ century, to protection in the late $20^{\text {th }}$ century to nuisance control since 2010s. We seek a comprehensive policy that achieves a balanced approach to accommodate three different roles of marine mammals: a natural resource, a component of marine ecosystems and agents of damage to fisheries (Lavigne 2003). The situation regarding large cetaceans is of a different nature, compared to that for seals and sea lions. We also discuss the method of consensus building in changing policies for wildlife management of these marine mammals.

Adaptive management for Steller sea lions in Japanese waters. Steller sea lions (Eumetopias jubatus) consist of two subspecies, Western Steller sea lion (E. jubatus jubatus) and Loughlin's northern sea lion (E. jubatus monteriensis; Phillips et al. 2009). Western Steller sea lions are 
distributed in the Bering Sea and the Sea of Okhotsk. They are further divided into two genetically distinct populations, the central stock and the Asian stock. The former is distributed along the Aleutian Islands and the Alaskan Peninsula, whereas the latter is distributed along the Kamchatka Peninsula and in the Okhotsk Sea (Phillips et al. 2009). Loughlin's northern sea lions are distributed along the west coast of the North American continent. The total population size of the species is still large and the extent of population reduction over three generations has been $28 \%$, which does not satisfy the IUCN Redlist Criteria (IUCN [International Union for Conservation of Nature] 2014). Therefore this species was down listed from the IUCN Redlist of Threatened Species (hereafter abbreviated by "IUCN Redlist") in 2012. However, the western Steller sea lions are still listed as Endangered because the Bering Sea population of this species has decreased since the 1960s and has not recovered yet (Burkanov and Loughlin 2005).

The Asian population of western Steller sea lions breeds in northern Okhotsk, with Sakhalin and the Kuril Islands as breeding sites. They migrate from their rookeries to waters around the Hokkaido and Aomori Prefectures in northern Japan to over-winter. The Asian population had also experienced a steep decline by the 1970s. Since then, the western component of the population has been recovering at an annual increase rate of $4 \%$, although the recovery of the eastern component of this population (i. e. the Kamchatka, Commander and western Bering rookeries) remains awaited (Burkanov and Loughlin 2005, Hattori et al. 2009). Economic status and major fisheries resource differ between these regions. The economic damage caused to fisheries by Steller sea lions increased to ca. 600 million JPY (Japanese yen) annually in early 1990s (Figure 1).

Because of such substantial fisheries damage, more than 200 sea lions were culled each year, for the period 1960 - 1993 (Hattori and Yamamura 2014). Because of international movements for protection of endangered marine mammals, the Japanese Fisheries Agency determined that the limit for culling Steller sea lions be reduced to 116 per year. However, there was no specific

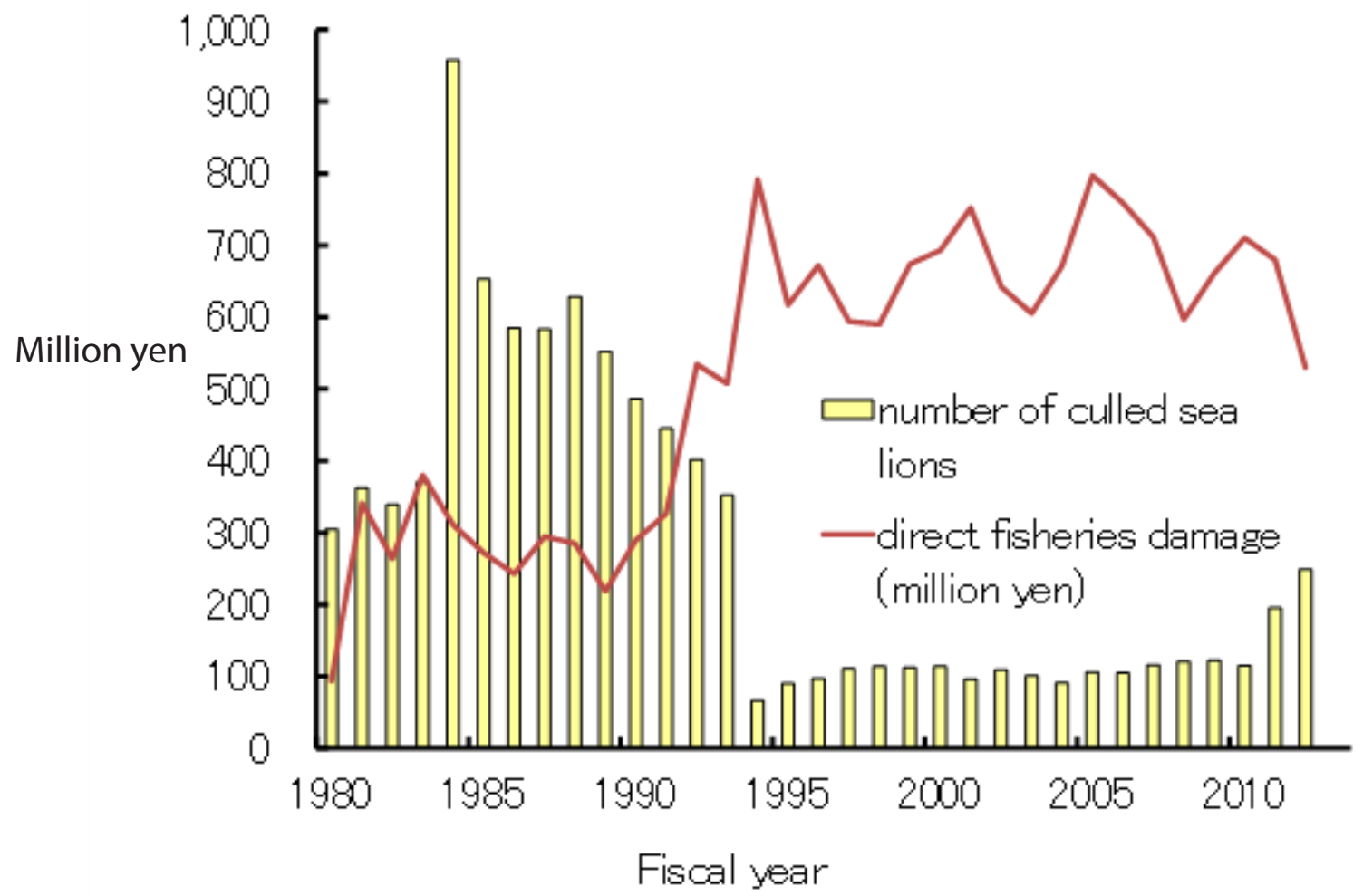

Figure 1. Direct fisheries damage by Steller sea lions in the Hokkaido Prefecture and the number of culled sea lions in Japan (Source: Japanese Fisheries Agency 2014). 
scientific basis for this number of 116 . To provide a more scientifically based policy for sea lions, the Working Group for Stock Assessment of Steller Sea Lions (hereafter abbreviated by WG-SSL), constituted by the Japanese Fisheries Agency, used the concept of potential biological removal (PBR, Wade 1998). PBR is defined as: PBR $=N_{\min } R_{\max } F_{l} / 2$, where $N_{\min }$ is a conservative estimate of population size; $R_{\max }$ is the maximum population growth rate, and $F_{r}$ is a recovery factor that is 0.1 for Endangered species, 0.5 for Vulnerable species, and 1 for common species. The WG$\mathrm{SSL}$ used $N_{\min }=5063$ from aerial surveys (Hattori et al., in preparation), $R_{\max }=0.12$ (Wade, 1998), and $F_{r}=0.75$ because the sea lions were classified as Vulnerable in the Japanese Redlist and their population was increasing. Therefore PBR was calculated to be 227 . It should be noted that PBR needs to incorporate all kinds of anthropological mortality, e. g., bycatch; but the bycatch number was, however, not reported. According to the press release on August 1, 2007 by the Japanese Fisheries Agency (http://www.jfa.maff.go.jp/j/press/arc/pdf/081001.pdf), the number of bycatch was between 53 and 107 per year. WG-SSL supposed that the number of bycatch was 107 and advised the culling limit to be set to 120 per year in 2007 (Matsuda et al. 2009).

Damage to fisheries has fluctuated from year to year, so that the need for culling of sea lions varied annually. In 2010, WG-SSL used that $N_{\min }=5,157$, the number of bycatch was 103 and $F_{r}=$ 1 because the population trends consistently increased. To allow for a more flexible policy, the Japanese Fisheries Agency introduced a "block-quota" system for the culling of Steller sea lions in 2010. The block-quota means that the culling limit is regulated within five years. There is a 5 -year quota of 1,030 that the number taken each year can vary as long as the total is not exceeded over the five year period, and that the number 206 will be re-evaluated and reset after five years. Consequently the number of sea lions culled has increased since 2011 (Figure 1).

In 2012, the Japanese Ministry of Environment (MoE) revised the Japanese Redlist, and the Japanese sub-population of Steller sea lions was reclassified from Vulnerable to Near Threatened. In 2013, the Japan Fisheries Agency constituted the Committee for Revision of Steller Sea Lions Management (CRSSLM). The members of the CRSSLM include marine biologists and fisheries scientists. In addition, staff from the fisheries organizations and from international environmental organizations are also invited as members. The CRSSLM agreed to start a population control policy for Steller sea lions in 2014. The cull limit was set with the intention to decrease the population size by $40 \%$ within the next 10 years. The CRSSLM used the concept of adaptive management for this management plan. Based on the management evaluation scheme using both production model and age-structured model, the average culling limit is 501 per year (Kitakado et al. unpublished). The CRSSLM will monitor and evaluate the future status of the Steller sea lion population and of fisheries damage. Once the population size is estimated to have decreased by $40 \%$, the culling limit will be decreased to the value given by PBR with $F_{r}=1$. WWF (World Wildlife Fund for Nature) Japan was included, while the government has not invited WWF in the issue of coastal whaling as mentioned below.

Wildlife management plan for harbor seals in Cape Erimo. The Harbor seal (Phoca vitulina) is a common species that is found in Hudson Bay, the Eastern Atlantic, the Western Atlantic, the Eastern Pacific and the Western Pacific, with a different subspecies in each of these regions. Western Pacific harbor seals (P. vitulina stejnegeri) are found in the Commander Islands, Aleutians, Kamchatka and throughout the Kuril Islands to Hokkaido in the western Pacific (IUCN 2014). The population of the whole subspecies is stable and is classified as Least Concern in the IUCN Redlist (IUCN 2014). However, the Erimo population that is found near Cape Erimo, Hokkaido, Japan, is genetically isolated (Nakagawa et al. 2010). This population, including pups (0 year olds) has decreased, and numbered only ca. 150 in the early 1980s, probably because of commercial harvesting of seals and of human activities including coastal fisheries (Kobayashi et al. 2014). There is another Japanese population of these seals, from Daikoku Island to Habomai Islands as 
identified by Mitchondrial DNA analysis (Nakagawa et al. 2010) and tagging studies, southeastern Hokkaido, Japan. Its average population growth rate has been approximately $5 \%$, per annum over the past 30 years, and recently bycatch has been the most important factor affecting this harbor seal population. Moreover, the number of haul-out sites has not increased in Japan, and approximately $50 \%$ of these seals are found in the vicinity of Cape Erimo. The population size, however, has begun to increase since the 1980s (Figure 2). Even so, the harbor seal was listed as Endangered in 1992 on the Japanese Redlist.

Although the body size of a harbor seal is smaller than that of a Steller sea lion, harbor seals are also considered as a pest animal for coastal fisheries (Wickens 1995). Their estimated damage to salmon fisheries at Erimo in the Hokkaido Prefecture was ca. 40 million yen in 2013 (MoE 2014). On the other hand, Cape Erimo is a sightseeing spot for harbor seals. Therefore even fishermen do not advocate total eradication of harbor seals. By-caught individuals are usually 0 year olds, while nuisance seals are older.

The abundance of the Erimo population of harbor seals has been increasing since the 1980s; consequently MoE revised the former Japanese Redlist in which the Japanese population of harbor seals was listed as Endangered, and changed it status to Vulnerable after the Redlist was revised in 2012. This revision was widely supported by local fishermen, therefore that Department promised to restart the reduction of the Erimo population by culling in 2013. Following that promise, the Conservation and Management Committee for Harbor Seals, constituted by the MoE, advised that 40 individuals as the cull limit for temporal decrease in the population and in economic damage, and would secure the permanence of this endangered population. However, the MoE later reconsidered their position and decided against restarting the cull of harbor seals in 2013. The fishermen consequently developed a lack of trust in the MoE because MoE did not keep their earlier promise to fishermen.

The MoE revised Japanese Redlist in 2000, 2007 and 2012. Moreover, seals have been protected under the Wildlife Protection, Management and the Hunting Law since 2003, while Steller sea lions are controlled by the Japanese Fisheries Agency.

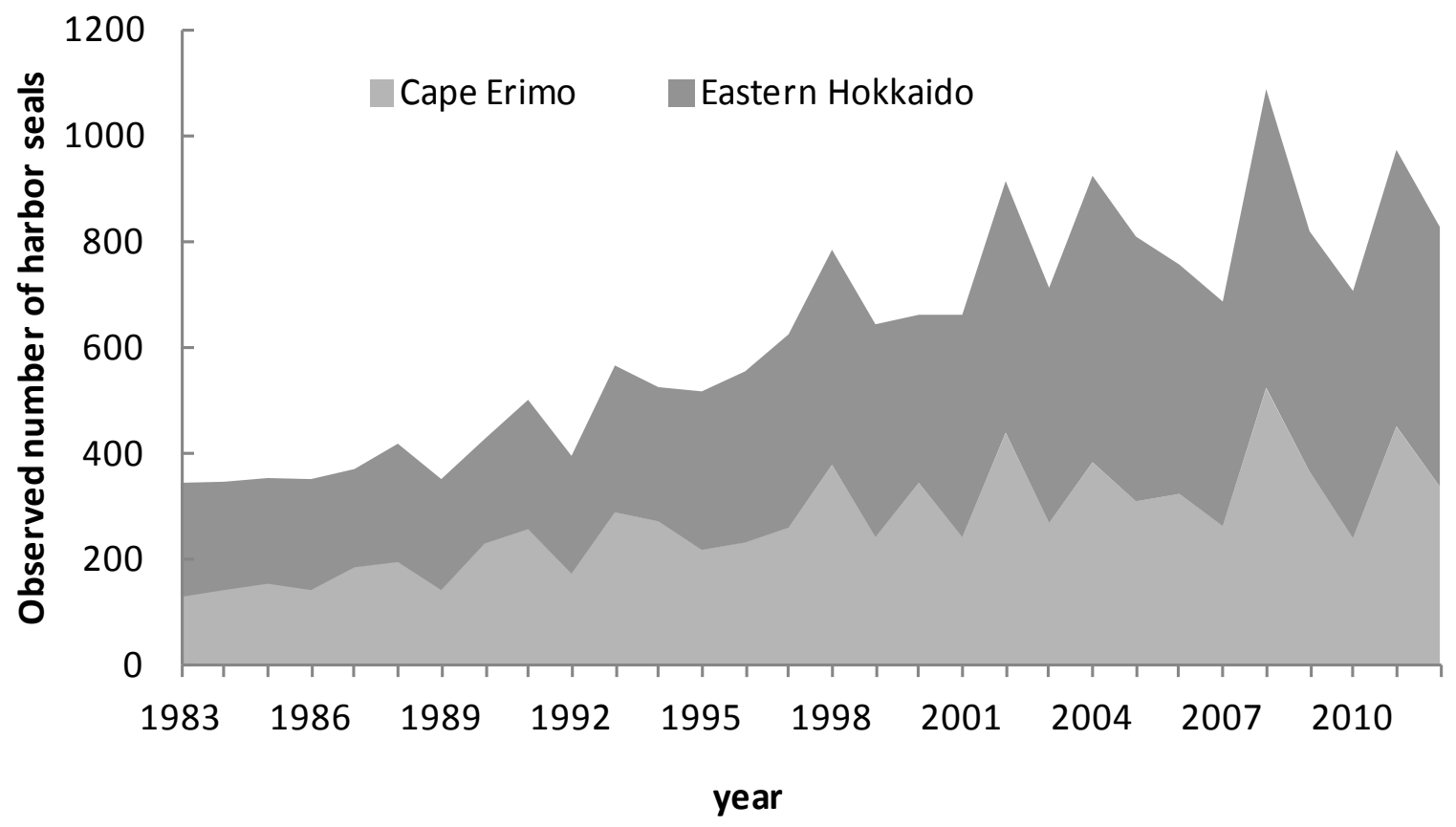

Figure 2. The number of Kuril harbor seals at the 10 haul-out sites in south and eastern Hokkaido during molting periods, as compiled by Kobayashi et al. (2014). Data for Cape Erimo during 2011-2012 is given by Kobayashi et al. (unpublished). 
When the $10^{\text {th }}$ Meeting of the Conference of Parties to the Convention on Biological Diversity was held in Nagoya, Japan in 2010, the MoE released a plan to promote the inclusion of marine fisheries resources including cetaceans in the Japanese Redlist. The Committee for the Marine Redlist determined the evaluation method, according to which a species is not listed if the extinction risk is assessed and it is less than that specified by IUCN's Criterion E, even though that species satisfies other IUCN's criteria. Therefore that species is to be listed. This assessment methodology is therefore weaker than the IUCN's criteria but it is identical to the criteria used for Japanese vascular plants (Yahara et al. 1998; Matsuda et al. 2003).

Inconsistencies can arise between the application of IUCN's Redlist criterion E referring to extinction risk assessment and of other IUCN's criteria. Since 1996, southern bluefin tuna (Thunnus maccoyii), has been listed as Critically Endangered by IUCN because of a more than $80 \%$ reduction in population size within the past three generations (Matsuda et al. 1997). However Matsuda et al. $(1997,1998)$ evaluated that the extinction risk of this species does not satisfy Criterion $E(>50 \%$ within the next 10 years or three generations), but would be classified as Vulnerable because of a more than $10 \%$ risk that it fall below the minimum viable population size (500 mature individuals) within the next 100 years.

The MoE constituted the Science Council (SC) for Harbor Seals in 2014. As a first step, the SC evaluated the extinction risk for the various Japanese populations of harbor seals, using population viability analysis. If the extinction risk is definitely less than IUCN's criterion $E$, the MoE will ask the science committee for Japanese Redlist to reconsider the current classification of harbor seal. MoE sets the endpoint as the extinction of the Erimo population because that population is almost isolated and is the southern limit of the distribution of harbor seals. If the classification of harbor seal is changed from Vulnerable to Near Threatened, MoE will change its policy from conservation to population control plan for harbor seals by March 2016.

Relationships between the population size of pest animals and the damage they cause to fisheries and agriculture are still uncertain. In the case of the Brown Bear Conservation and Management Plan by Hokkaido Prefecture enforced in 2013, two categories of bears are recognized, the non-nuisance and the nuisance individuals based on their behavior. This distinction is reflected in the language of the indigenous Ainu people, who call non-nuisance bears "kimun-kamuy" or "god in the mountain" and nuisance bears "wen-kamuy" or "bad god". Non-nuisance bears either evade or ignore human presence and do not cause any agricultural damage. Nuisance bears are aggressive toward humans or tend to invade crop fields (Ohta et al. 2012). Before culling, nuisance bears can be discouraged by their behavior, especially when they encounter people or they approach the neighborhood of farms. After culling, their status can be confirmed by their stomach contents, whether agricultural crops or wild organisms. In addition, the Hokkaido Government monitors the estimated number of nuisance bears based on observations reported by residents.

Such a distinction may be applied to marine pest animals. If so, only nuisance individuals should be culled to decrease damage on fisheries. Culling individuals within or near fishing grounds is probably more effective than culling elsewhere. In Scotland, the conflict between people and seals is controlled by selective removal of so-called "problem" or "rogue" animals (Graham et al. 2011), which correspond to what is meant here by "nuisance". A monitoring method need to be established to estimate both the total population size and the number of nuisance seals in the Cape Erimo region and their trends over time.

Extinction Risk Assessment for the Japanese Dugong population. In response to a comment by the Governor of Okinawa Prefecture on the Environmental Impact Statement (EIS) for a US Military Base in the Henoko District (hereafter "Henoko Base"), we here defined the extinction risk 
for the Japanese population of dugong as all individual disappear. We evaluated the extinction risk by using an individual-based model under the following assumptions for life history parameters. The reproduction rate of a mature female is $1 / 3$ per year if at least one mature male persists in the population. Females and males mature at nine years old. A female produces at most 1 pup per year. The sex ratio at birth is $1: 1$. The survival rate from birth to one year of age is $80 \%$. The annual survival rate of an individual of at least one year of age is $95 \%$. If the population size is larger than the carrying capacity, there is no reproduction. The calculations consider that the population goes extinct if the population size becomes one because a single individual alone cannot reproduce.

In addition, the following initial conditions were assumed (Table 1). The initial population size is six individuals despite the fact that only three individuals were found during the EIS. The carrying capacity depends on the area of sea grass beds in Ryukyu Islands, which was 6,902 ha (Okinawa Defense Bureau 2012). The carrying capacity before the construction of the Henoko Base was 493 individuals because each individual requires $c a$. 14 ha of sea grass beds for food, as assumed by the Okinawa Defense Bureau (2012). It is assumed that no individual died as a result of the construction of Henoko Base, because the patrol system will be installed so that construction operation stops when individuals approach into the construction site. The carrying capacity is taken to have decreased by 6 individuals (493 to 487) due to the sea grass beds in Oura Bay, the location of the Henoko Base, having decreased by 78 ha (Okinawa Defense Bureau 2012). Life history parameters that are used here are listed in Table 1.

There are many uncertainties in these assumptions. Unlike the assumptions usually made for assessments in conservation biology, these assumptions are probably optimistic except as regards the assumption that the total area is limited to Okinawa Main Island and its vicinity because the purpose of this assessment is to check current presumptions that the extinction risk for the Japanese dugong is very high even under optimistic assumptions.

Figure 3 shows the extinction risk from 1000 trials of an individual-based model (Boyce 1992), in which the assumptions above were used. Because carrying capacity is much larger than the present population size, the reduction of carrying capacity caused by the Henoko Base construction leads

Table 1. Life history parameters for dugong that are assumed.

\begin{tabular}{|c|c|c|c|}
\hline & $\begin{array}{l}\text { Quantity used } \\
\text { here }\end{array}$ & $\begin{array}{l}\text { Quantity in } \\
\text { literature }\end{array}$ & Literature cited \\
\hline Initial population size & 6 & 3 & Okinawa Defense Bureau 2012 \\
\hline Area of sea grass beds (ha) & 6902 & 6902 & Okinawa Defense Bureau 2012 \\
\hline $\begin{array}{l}\text { Area of sea grass beds that an individual dugong requires } \\
\text { (ha) }\end{array}$ & 14 & 14 & Okinawa Defense Bureau 2012 \\
\hline $\begin{array}{l}\text { Loss of sea grass beds caused by the construction of } \\
\text { Henoko Base }\end{array}$ & 78 & 78 & Okinawa Defense Bureau 2012 \\
\hline $\begin{array}{l}\text { Carrying capacity in Ryukyu Archipelago before the } \\
\text { construction of Henoko Base }\end{array}$ & 493 & & \\
\hline $\begin{array}{l}\text { Carrying capacity in Ryukyu Archipelago after the } \\
\text { construction of Henoko Base }\end{array}$ & 487 & & \\
\hline Clutch size per year & 1 & 1 & \\
\hline Inter-birth interval (y.) & 3 & $3-7$. & Marsh et al., 1984 \\
\hline Sex ratio at birth & 0.50 & 0.55 & Marsh et al., 1984 \\
\hline Fecundity (/y) & 0.17 & & \\
\hline Age at maturity (y.) & 9 & ca. 9 & Marsh et al., 1984 \\
\hline Survival rate until 1 year old & $80 \%$ & $81 \%$ & Heinsohn et al., 2004 \\
\hline Annual survival rate after 1 year old & $95 \%$ & $92 \%-97 \%$ & Heinsohn et al., 2004 \\
\hline Maximum age & 99 & 73 & Heinsohn et al., 2004 \\
\hline
\end{tabular}


only to an extremely small increase in the extinction risk. Because the initial population size is very small, the extinction risk is very high even under optimistic assumptions concerning survival and reproduction rates. Even though the impact of the Base construction on the increase in the extinction risk of dugong is small, the Okinawa Defense Bureau (2012) has declared its intention to undertake some mitigation measures to maintain the total area of sea grass beds. Other measures such as artificial breeding would probably be difficult for dugongs.

Whales and whaling in Japanese waters. Coastal whaling by spear fishing and drive net fishing has existed in several fisheries locations in Japan since at least the $16^{\text {th }}$ century. Modern whaling in Japan began in the $19^{\text {th }}$ century. Whalers in these historical villages have worked in the Antarctic whaling. American whalers also hunted sperm whales (Physeter macrocephalus) in northwestern Pacific in the $19^{\text {th }}$ century until the 1960 s.

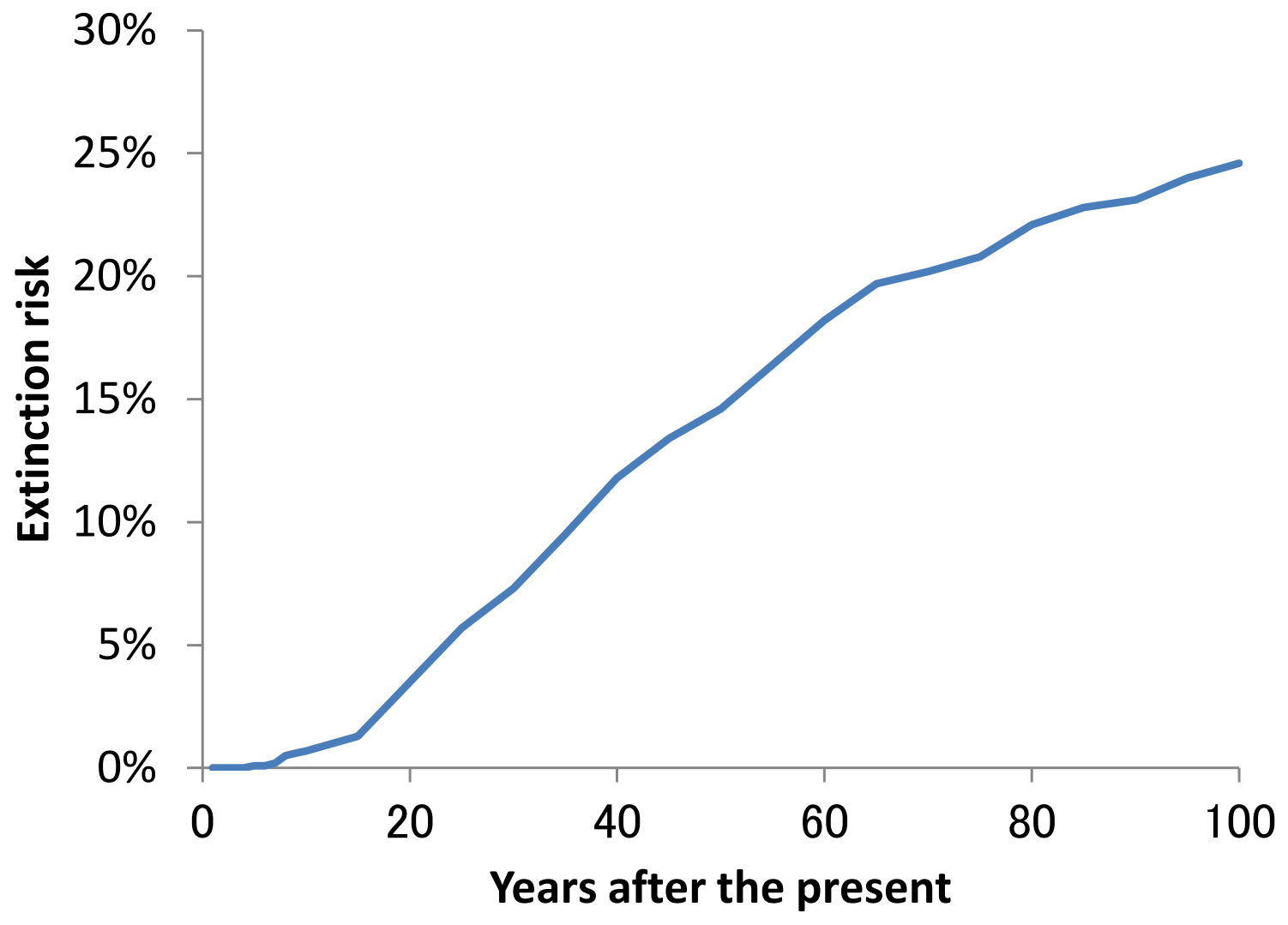

Figure 3. The extinction risk (see main text for definition) for the Japanese dugong population from 1,000 trials of the individualbased model.

Because of overexploitation, hunting of the blue whale (Balaenoptera musculus), fin whale (B. physalus) and sei whale (B. borealis) was banned in 1964, 1975 and 1975, respectively. Hunting of the Bryde's whale (B. brydei) and north Pacific minke whale (B. acutorostrata acutorostrata) had started in 1964 and 1984, respectively. The abundances of minke whale has never been very low (Hakamada unpublished). Since 1986, commercial whaling of all large cetaceans has ceased to the moratorium enacted by the International Whaling Commission. Whaling of minke whales in north Pacific region under Special Scientific Permit in the North Pacific (JARPN) started in 1994. Similar whaling on sei, Bryde's and sperm whales in north Pacific region started in 2000.

The Revised Management Procedure (RMP) was adopted by the Scientific Committee of IWC in 1993 and adopted by the Commission itself in 1994. The RMP is based on the idea of adaptive management and is robust against uncertainties in measurement and implementation errors (Tanaka 1980). Whale populations that were being harvested at the time the moratorium came into force in 1986 are not listed as threatened species in the IUCN's Redlist (Table 1). Catching 
of these species was suspended pending the development of a robust management procedure. However, even though the RMP has been adopted, the IWC has not yet reached agreement on a Revised Management Scheme which includes other aspects such as inspection schemes. Unlike Japan, Norway and Iceland have restarted commercial whaling effectively under the RMP. This concept has also been applied to deer and bear management in the Hokkaido Prefecture (Kaji et al. 2010; Ohta et al. 2012).

Japanese whalers also harvest small cetaceans and dolphins (Table 2). Short-finned pilot whale and Dall's porpoise appear as two different forms in Japanese waters. The annual catch limits for the small-type whaling operation are organized by Fisheries Agency of Japan in consultation with the scientific advices by experts of National Research Institute of Far Seas Fisheries. Japan Fisheries Research Agency compiles catch amounts and bycatches, assess the stock levels of small whales and dolphins in Japanese coastal regions, and determined catch limits for each species under the RMP. Japanese whalers catch large cetaceans including the minke whale both in Japanese waters and outside of Japanese Exclusive Economic Zone (EEZ) as shown in Figure 4.

Major press and academic societies in Japan do not disagree with commercial whaling if the target species is not threatened. Most of them explicitly support the restart of coastal whaling. Some Japanese environmental groups have disagreed or still disagree with commercial whaling. Greenpeace Japan has campaigned against whaling. WWF (World Wildlife Fund for Nature) Japan campaigned against whaling during the 1970s to the 1990s, but changed their policy in 2002 to

Table 2. Cetacean species and forms that are taken by Japanese whaling or listed as threatened by the Mammal Society of Japan(1997). Catch limits are as determined by JFA in 2001. The ranking in the IUCN's Redlist is as at September 2014 (NE: Not Evaluated, DD: Data Deficient, LC: Least Concern, VU: Vulnerable, EN: Endangered, CR: Critically Endangered).

\begin{tabular}{|c|c|c|c|c|}
\hline Common name & Academic name & Catch quota & MSJ* & IUCN** \\
\hline \multicolumn{5}{|l|}{ (Small cetaceans including dolphins) } \\
\hline North Pacific bottlenose whale & Berardius bairdii & 66 & Rare & $\mathrm{DD}$ \\
\hline short-finned pilot whale (southern form) & Globicephala macrorhyncus & 250 & & \\
\hline short-finned pilot whale (northern form) & Globicephala macrorhyncus & 36 & & \\
\hline Dall's porpoise (Dalli type) & Phocoenoides dalli & 7149 & & LC \\
\hline Dall's porpoise (Truei type) & Phocoenoides dalli & 6916 & & \\
\hline striped dolphin & Stenella coeruleoalba & 610 & VU & LC \\
\hline bottlenose dolphin & Tursiops truncatus & 730 & & \\
\hline Risso's dolphin & Grampus griseus & 496 & & \\
\hline pantropical spotted dolphin & Stenella attenuate & 651 & & \\
\hline false killer whale & Pseudorca crassidens & 120 & & \\
\hline Pacific white-sided dolphin & Lagenorhynchus obliquidens & 360 & & LC \\
\hline finless porpoise & Neophocaena phocaenoides & 0 & $C R$ & VU \\
\hline \multicolumn{5}{|c|}{ (large cetaceans, catch quota is determined by scientific whaling outside Japanese EEZ) } \\
\hline Blue whale & Balaenoptera musculus & 0 & EN & EN \\
\hline Fin whale & Balaenoptera physalus & 0 & EN & EN \\
\hline Sei whale & Balaenoptera borealis & 100 & VU & EN \\
\hline Bryde whale & Balaenoptera brydei & 50 & VU & $\mathrm{DD}$ \\
\hline Minke whale & B. acutorostrata acutorostrata & 220 & & LC \\
\hline Sperm whale & Physeter macrocephalus & 10 & Rare & VU \\
\hline Humpback whale & Megaptera novaeangliae & 0 & VU & LC \\
\hline Right whale & Eubalaena japonica & 0 & EN & NE \\
\hline Gray whale & Eschrichtius robustus & 0 & EN & LC \\
\hline
\end{tabular}

*The Mammalogical Society of Japan (1997); ** International Union of Conservation of Nature (2014). 


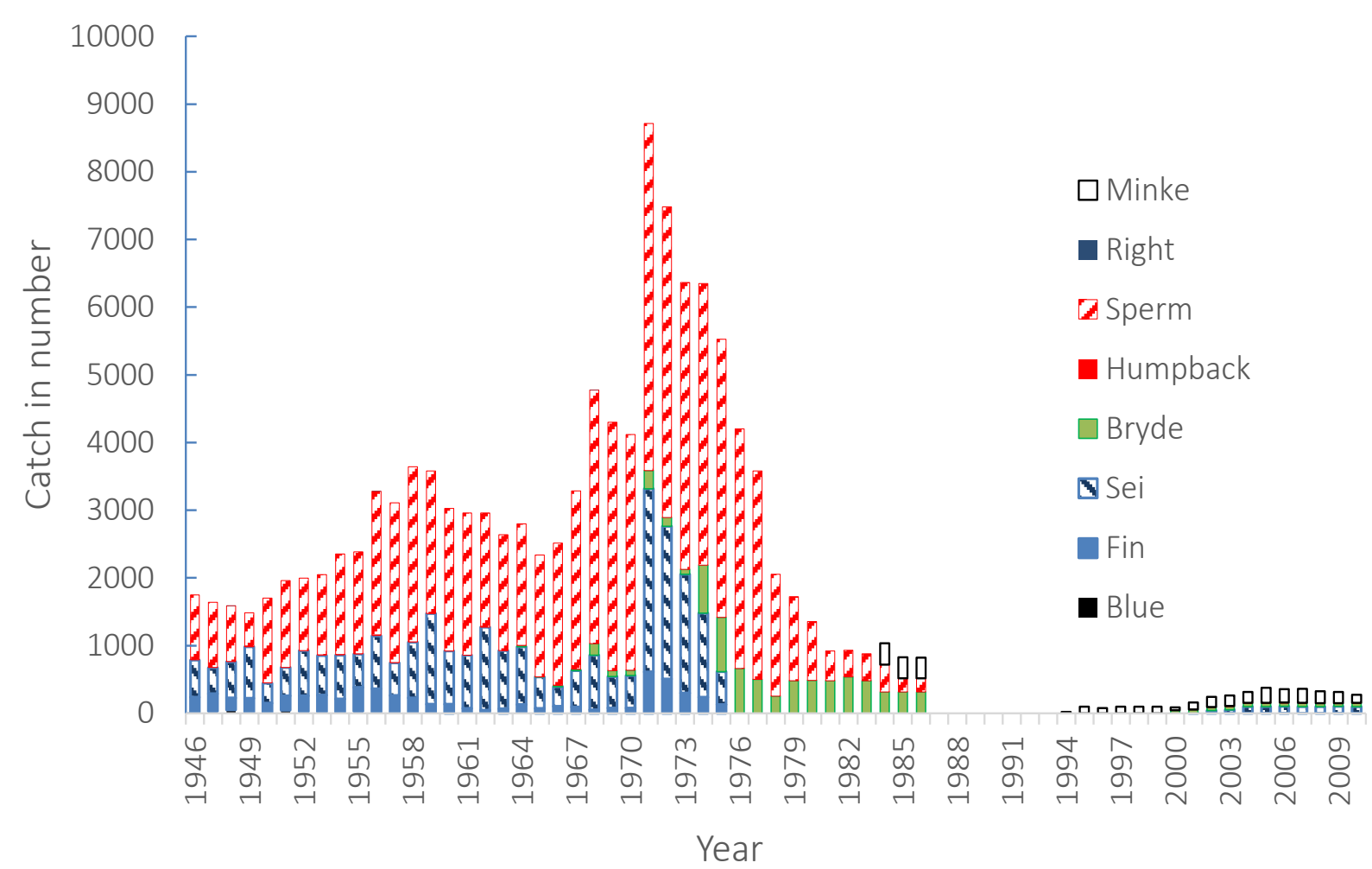

Figure 4. Catch in number of whales of Japan in the north hemisphere of Pacific (International Whaling Commission Database as of August, 2014: http://luna.pos.to/whale/sta.html).

support limited whaling. This statement was published in May 2005 (http://www.wwf.or.jp/ activities/2005/05/639501.html accessed on May 1, 2015), although western journalists criticized this as an "outrage" (e. g. The Guardian, April 2, 2002; http://www.theguardian.com/world/2002/ apr/02/japan.whaling accessed on May 1, 2015).

One of the reasons behind the international anti-whaling sentiment is probably distrust of whaling nations, including Japan. The management plan for commercial whaling needs to be enforced under a consensus with major environmental groups. Such an arrangement would be similar to that discussed above where the Japanese Fisheries Agency changed its management policy for Steller sea lion in a consensus arrangement which included WWF Japan.

\section{Discussion}

There are some similarities in Japanese wildlife management approaches between terrestrial and marine mammals and birds. Similar population trends where the population was once threatened, but has now recovered and causes serious damage to agriculture, forestry and fisheries are found for the Steller sea lion, harbor seal, spotted seal (Phoca largha), Japanese serow (Capricornis crispus), sika deer (Cervus nippon), wild boar (Sus scrofa), Japanese monkey (Macaca fuscata), brown bear (Ursus arctos) and great cormorant (Phalacrocorax carbo), although the timing of policy changes has differed amongst these species. For all of these species, Japanese laws, e. g., the Law for the Conservation of Endangered Species of Wild Fauna and Flora (hereafter abbreviated by LCES), the Law for Protection of Cultural Properties (LPCP) and the Wildlife Protection, Management and Hunting Law (WPHL), often discourage population control (e. $g$. through culling) because these laws were enacted when these wildlife populations were rare or threatened. The MoE periodically revises the Japanese Redlist and has rather less frequently revised the list of species that are protected under LCES. However, consensus building for policy 
change from protection to population control usually requires a long time, typically more than 10 years. The consumption of culled animals is often difficult to achieve because the market for meat and fur of wildlife almost disappeared at a time when these animals were threatened. Obtaining a hunting license is often discouraged in Japan. Nevertheless a professional hunter for Steller sea lions remains active, and has an individual catch quota of 60 , which is included in the catch limit mentioned above.

The Asian sea otter (Enhydra lutris lutris) and northern fur seals (Callorhinus ursinus) were once threatened but are now recovering. They have not yet caused appreciable damage to fisheries. However, fisheries damage caused by these species will possibly become serious in the near future.

These situations are considerably different from those for cetaceans in Japanese waters. Direct or indirect damage on fisheries by cetaceans is not known to occur except for a few cases in which whales collide with high speed vessels and fishing boats. The increase of cetacean biomass in Japanese waters may have had negative effects on fisheries resources (Tamura et al. 1998). Commercial exploitation might be possible for the non-threatened animals from the viewpoints of sustainability and international law (Stone 2001).

In conclusion, a management policy for each species of marine mammal depends on the current population status, behavioral characteristics and commercial value of the species. In the case of fisheries resources including cetaceans, the Japanese Fisheries Agency assesses the stock abundance to determine the catch limit if this species is not threatened (Table 2). In the case of threatened species that are not considered to be pest animals, the stock recovery plan is determined based on precautionary considerations. The major management measures are by-catch controls (Yatsu et al. 1995). In the case of pest species that are not threatened, the population is controlled by culling to decrease the damage to fisheries and to guarantee population persistence. In the case of animals considered pests that are threatened, both bycatch and culling limits are controlled so as to avoid a decrease in the population size. If the nuisance level differs amongst individuals, culling of nuisance individuals is probably an effective approach for both population persistence and decreasing the damage to fisheries. In the case of non-threatened and non-nuisance animals that are not used for consumptive purposes, no management measure are needed.

Furthermore, it is common to change a management policy if the population status and the society need a change in time, although some conflict between stakeholders may occur during changes of policy. At least, there has been a change in management policy that needs to be recognized.

\section{Acknowledgements}

We thank the members of the Working Group for Stock Assessment of Steller Sea Lions, F. Liu and S. Nishijima, S. Sasaki, Y. Shibata, K. Shimatani and A. Yamauchi at WWF Japanfor valuable comments and information. This work was supported in part by JSPS grant (25550102) to H. M. We express sincere thanks to the reviewers for their extensive revisions that improved our work.

\section{Resumen}

Introducción: Los mamíferos marinos son recursos naturales para los humanos; también son considerados pestes para algunas pesquerías, el daño a las pesquerías ocasionado por los lobos marinos de Steller al norte de Japón se ha incrementado desde 1990. El factor más importante que conduce la relación entre los humanos y los mamíferos marinos ha cambiado desde mediados del siglo 20 hasta principios del siglo 21, debido a los cambios en el nivel de amenaza de sus poblaciones, la demanda de estos recursos naturales y los programas para la conservación de los mamíferos marinos.

Material y métodos: En este trabajo hemos escogido cuatro diferentes taxa de mamíferos marinos para investigar los cambios en las políticas hacia los mamíferos marinos en Japón: lobos marinos de Steller, foca común, dugong y cetáceos. Algunos cetáceos han sido previamente sobre-explotados y ahora se encuentran amenazados y se espera 
de la recuperación de estas especies. Otros cetáceos de mayor tamaño nunca han estado amenazados, pero su explotación comercial fue prohibida por la Comisión Ballenera Internacional.

Resultados: En Japón todavía se capturan pequeños cetáceos en las pesquerías costeras y cetáceos de mayor tamaño para la investigación científica. Con excepción de los cetáceos, las políticas hacia los mamíferos marinos and cambiado, desde el uso del recurso a mediados del siglo 20, a su protección a finales del siglo 20 y hacia su control como peste desde el 2014. Los grupos ambientalistas han jugado un importante papel en la construcción de consenso en estos cambios de la política.

Discusión y conclusiones: Buscamos una estrategia comprensiva o un punto de vista que pueda balancear entre los tres aspectos de los mamíferos marinos: como un recurso natural, como participantes en el ecosistema marino, y como causantes de daño a las pesquerías. También discutimos la importancia del involucramiento de los interesados en el cambio de los programas para el manejo de la fauna silvestre, los que van desde la protección total hasta el control de las poblaciones.

Palabras clave: Cacería comercial de ballenas Japonesa, control de Poblaciones, dugong, foca Común, involucramiento de los Interesados, lobo marino de Steller, manejo adaptativo de fauna silvestre.

\section{Literature Cited}

Burkanov, N. V., And T. R. Loughuin. 2005. Distribution and abundance of Steller sea lions, Eumetopias jubatus, on the Asian Coast, 1720's-2005. Marine Fisheries Review 67:1-62.

Graham, I. M., R. N., Harris, I. Matejusová, and S. J. Middlemas. 2011. Do'rogue' seals exist? Implications for seal conservation in the UK. Animal Conservation 14:587-598.

Hattori, K., and O. Yamamura. 2014. Steller Sea Lion. In Fisheries Research Agency “Review of the state of world fishery resources". Pp. 1-7 http://kokushi.job.affrc.go.jp/H23/H23_55.pdf.

Hattori, K., and O. Yamamura. 2014. Steller Sea Lion. In Fisheries Research Agency"Review of the state of world fishery resources". Pp. 1-7 http://kokushi.job.affrc.go.jp/H23/H23_55.pdf.

Hattori, K., T. Isono, A. Wada, and O. Yamamura. 2009. The distribution of Steller sea lions (Eumetopias jubatus) in the Sea of Japan off Hokkaido, Japan: A preliminary report. Marine Mammal Science 25: 949-95.

Hoson, O., G. Ogura, N. Ohtaishi, and S. Oda. 2009. Are ancient dugong bones useful for analyses? Proceedings of the 4th International Symposium on SEASTAR 2000 and Asian Bio-logging Science (The 8th SEASTAR2000 workshop). 35-40

IUCN. 2014. The IUCN Redlist of Threatened Species. IUCN, http://www.iucnredlist.org/.

KaJl, K., H. Окada, M. Yamanaka, H. Matsuda, and T. Yabe. 2005. Irruption of a colonizing sika deer population. Journal of Wildlife Management 68: 889-899.

Kaj, K., T. Saitoh, H. Uno, H. Matsuda, and K. Yamamura. 2010. Adaptive management of a Sika deer population in Hokkaido, Japan: theory and practice. Population Ecology 52:373-387.

Kobayashi, Y., T. Kariya, J. Chishima, K. Fujil, K. Wada, S. Baba, T. Itoo, T., Nakaoka, M. Kawashima, S. Saito, N. Aokı, S. Hayama, Y. Osa, H. Osada, A. Niızuma, M. Suzukı, Y. Uekane, K. Hayashı, M. Kobayashi, N. Ohtaishi, and Y. Sakural. 2014. Population trends of the Kuril harbour seal Phoca vitulina stejnegeri from 1974 to 2010 in southeastern Hokkaido, Japan. Endangered Species Research 24:61-72.

LAVIGNE, D. M. 2003. Marine mammals and fisheries: the role of science in the culling debate. Pp. 31-47 in Marine mammals: fisheries tourism and management issues (Gales N, M. Hindell, and R. Kirkwood, eds.) CSIRO publications. Melbourne, Australia.

Marsh, H., G. E. Heinsohn, and L. M. Marsh. 1984. Breeding cycle, life history and population dynamics of the dugong, Dugong dugon (Sirenia: Dugongidae). Australian Journal of Zoology 32:767-788.

Matsuda, H., T. WAda, Y. TakeuchI, And Y. MatsumiYa. 1991. Alternative models for species replacement of pelagic fishes. Researches on Population Ecology 33:41-56.

Matsuda, H., T. Yahara, And Y. Uozumi. 1997. Is the tuna critically endangered? Extinction risk of a large and overexploited population. Ecological Research 12:345-356. 
Matsuda, H., Y. Takenaka, T. Yahara, and Y. Uozumi. 1998. Extinction risk assessment of declining wild populations: in the case of the southern bluefin tuna. Researches on Population Ecology 40:271-278.

Matsuda, H., S. Serizawa, K. Ueda, T. Kato, and T. Yahara. 2003. Extinction Risk Assessment of Vascular Plants in the 2005 World Exposition, Japan. Chemosphere 53:325-336.

Matsuda, H., M. Makino, and Y. Sakurai. 2009. Development of adaptive marine ecosystem management and co-management plan in Shiretoko World Natural Heritage Site. Biological Conservation 142:19371942.

Mammalogical Society of Japan (ed.). 1997. Red Data of Japanese mammals, Bun-ichi. Tokyo, Japan (in Japanese).

Ministry of Environment, Japan. 2014. The Conservation and Management Plan for Harbor Seals in Erimo Region, Ministry of Environment, Japan (in Japanese). http://www.env.go.jp/press/file_view. php?serial $=24493 \&$ hou_id $=18131$

Nakagawa, E., M. Kobayashi, M. Suzuki, and T. Tsubota. 2010. Genetic variation in the harbor seal (Phoca vitulina) and spotted seal (Phoca largha) around Hokkaido, Japan, based on mitochondrial cytochrome b sequences. Zoological Science 27:263-268.

Оhta, U., M. Jusup, T. Mano, H. Tsuruga, and H. Matsuda. 2012. Adaptive management of the brown bear population in Hokkaido, Japan. Ecological Modelling 242:20-27.

Okinawa Defense Bureau. 2012. Revised Environmental Impact Statement for Futenma Replacement Facility Construction Project Section 6-16 Dugong. Okinawa, Japan. (http://www.mod.go.jp/rdb/ okinawa/07oshirase/chotatsu/hyoukasyohosei/140.pdf in Japanese, accessed on September 25, 2014).

Ounama, S. 1971. Taxes of the Yaeyama Islands. San-ichi Syobou, Tokyo (in Japanese)

Phillips, C. D., J. W. Bickham, J. C. Patton, and T. S. Gelatt. 2009. Systematics of Steller sea lions (Eumetopias jubatus): subspecies recognition based on concordance of genetics and morphometrics. Natural Science Research Laboratory, Museum of Texas Tech University.

Pompa, S., P. R. Ehrlich, and G. Ceballos. 2011. Global distribution and conservation of marine mammals. Proceedings of National Academy Science 108:13600-13605.

Stone, C. D. 2001. Summing Up: Whaling and Its Critics. Pp 269-291 in Towards a sustainable whaling regime (Friedheim, R. L, ed.). University of Washington Press. Seattle, EE.UU.

Tamura, T., Y. Fujise, and K. Shimazaki. 1998. Diet of minke whales Balaenoptera acutorostrata in the northwestern part of the North Pacific the summer, 1994 and 1995. Fisheries Science 64:71-76.

TANAKA, S. 1980. A theoretical consideration on the management of a stock-fishery system by catch quota and on its dynamical properties. Bulletin of the Japanese Society of Scientific Fisheries 46:1477-1482.

WADE, P. R. 1998. Calculating limits to the allowable human-caused mortality of cetaceans and pinnipeds. Marine Mammal Science 14: 1-37

Wickens, P. A. 1995. A Review of Operational Interactions between Pinnipeds and Fisheries. FAO Fisheries Technical Paper 346:1-86.

Yahara, T., T. Kato, K. Inoue, M. Yokota, Y. Kadono, S. Serizawa, H. Takahashi, N. Kawakubo, H. Nagamasu, K. SuzUKI, K., Ueda, AND Y. Kadota. 1998. Redlist of Japanese vascular plants: summary of methods and results. Proceedings of Japanese Society of Plant Taxonomists 13: 89-96.

Yatsu, A., K. Hiramatsu, and S. Hayase. 1995. A Review of the Japanese squid driftnet fishery with notes on the cetacean bycatch. Report of the International Whaling Commission (Special issue 15): 365-379.

Yodzis, P. 2001. Must top predators be culled for the sake of fisheries? Trends in Ecology and Evolution 16:78-84. 
Summited: September 30, 2014

Review: April 20, 2015

Accepted: May 6, 2015

Associated editor: Juan Pablo Gallo 